\title{
Place Marketing and Urban Retail Agglomerations: an examination of shoppers place attractiveness perceptions
}

Christoph Teller ${ }^{\dagger}$, Jonathan R. Elms ${ }^{\dagger \dagger}$, Jennifer A. Thomson ${ }^{\dagger \dagger \dagger}$, Andrew Paddison ${ }^{\dagger \dagger \dagger}$

$\dagger \ldots$ [corresponding author] Institute for Retail Studies, University of Stirling; Stirling FK9 4LA; United Kingdom; Tel: ++44 (0) 178646 6454; Fax: ++44 (0) 178646 5290; Email: christoph.teller@stir.ac.uk;

$\dagger \dagger \ldots$ Institute for Retail Studies, University of Stirling; Stirling FK9 4LA; Scotland/United Kingdom; Tel: ++44 (0) 1786 467375; Fax: ++44 (0) 1786 464745;

Email: j.r.elms@stir.ac.uk;

$\dagger \dagger \dagger \ldots$ Division of Marketing, University of Stirling; Stirling FK9 4LA; United Kingdom; Tel: + 44 (0) 1786 467412; Fax: + 44 (0) 1786 464745; Email: j.a.thomson@stir.ac.uk;

$\uparrow \uparrow \uparrow \uparrow \ldots$ Institute for Retail Studies, University of Stirling; Stirling FK9 4LA; Scotland/United Kingdom; Tel: + + 44 (0) 1786 467397; Fax: ++ 44 (0) 1786 464745;

Email: a.r.paddison@stir.ac.uk;

Submitted to the Journal of Place Branding and Public Diplomacy on $26^{\text {th }}$ of March 2010 


\title{
Place Marketing and Urban Retail Agglomerations: an examination of shoppers place attractiveness perceptions
}

\begin{abstract}
This study approaches the perceptions of shoppers towards urban retail agglomerations from the perspective of place marketing. Acknowledging that place marketers need to be mindful of how place users can be best fulfilled this research conceptualises the agglomeration as a place marketing site. The literature reveals the role of place users, in particular the retail customers, in the place formation process. As such an evaluation framework proposes antecedents of (retail related) place attractiveness in order to understand what the key drivers of this behaviour are. An empirical study is presented involving almost five hundred face-to-face interviews of shoppers at the time they visit a town centre. The results show that the retail tenant mix and the atmosphere influence attractiveness most significantly. Critical reflection of the literature with respect to the empirical findings reveals the crucial necessity to understand and integrate the place user's point of view into the concept of place marketing. This research addresses a gap in the literature on place marketing focussing on place users' perceptions as opposed to the dominant theme of place actor's strategic needs.
\end{abstract}

Keywords: place marketing, retail, place users, retail location, consumer 


\section{Introduction}

The pattern forming of retail locations has historically been characterised by a need, together with a preference, for clustering (Guy, 2007; Teller, 2008). Through situating themselves geographically with other retailers, retail agglomerations have formed subsequently creating opportunities for place marketing activities. Where there are cumulative benefits for the producers, such as retailers, to think collectively, rather than only competitively, there may be a rationale for the urban place marketing product to reflect this. Developing an understanding of the perceptions of place users, as part of this 'place formation' process, is included within this product framework. Contextually, this is important when considering that competitive pressures on locations, as noted by Short and Kim (1998), are intensifying. 'Place formation' should allow place marketers to be better informed as to how they can reinforce their current markets whilst generating new ones. As such, if place marketing produces a 'harmonious city' (van den Berg et al., 1990) the measurement of this should be centred on whether it meets the needs of its target markets.

Typologically, two agglomeration formats can be identified: evolved retail agglomerations and created retail agglomerations (Teller, 2008). Evolved agglomerations encompasses retailing within central business districts, inner cities and main streets, whilst created agglomerations include shopping centres and malls of differing scales together with retail parks, outlet centres and strip centres. Whereas the former may have developed organically, be under multiple ownership and exist without any overarching organisational entity to promote it, the latter are conceived, planned and launched as collective retail forms that are typically marketed in a co-ordinated manner (Teller and Elms, 2009).

Notwithstanding these differences between agglomeration formats, together with the diversity of retail forms within each format, the need to maintain and enhance competitiveness is universal. Where agglomerations can identify what constitutes retail 
agglomeration attractiveness amongst consumers (Teller and Reutterer, 2008), a degree of competitive leverage can allow for a more appropriate, and potentially more marketable, product proposition to be offered. When attracting consumers, agglomerations can then capitalise on their status as locations that place users prefer. As outlined by Warnaby et al. (2002), place marketing activities should identify and then fulfil the market's expectations. Conceptualisation of this place marketing process, therefore, needs to recognise the importance of place users and how they are embedded as 'consumers' within that element, together with 'producers', subsequently feeding into the 'market' (Ashworth and Voogd, 1994).

Reflecting on the literature it is evident that the focus of most place marketing research has, understandably, been on the supply-side perspective of those engaged in, and tasked with, place marketing strategies (e.g. Warnaby et al., 2005). A gap in understanding therefore has emerged in understanding the consumer perspective. To address this, measuring the perceptions of place users should allow for a basis of comparison against the supply-side research, which focuses on 'place actors'.

The aim of this paper therefore is to investigate the role of retailing within the concept of (urban) place marketing on a theoretical and empirical level. More specifically the study will examine place users i.e. shoppers perceptions of an urban retail agglomeration. The results will be relevant to place marketers in illustrating how place users can be fulfilled. This paper is divided into six sections. After these introductory remarks a literature review discusses the role of place users in particular retail customers in the place formation process and the place marketing concept. After establishing an evaluation framework and proposed antecedents of retail related place attractiveness an empirical study is presented. The results of the model testing are consequently discussed with respect to the existing literature. 


\section{2. 'Place Formation' and the Place User's Role}

Place marketing literature has been developing since the 1970s (Kotler et al., 1999) with recent activity characterised by the operationalisation of increasingly sophisticated marketing techniques (Warnaby et al., 2005). Although the underlying activity of place marketing has remained constant over time the application of practical marketing techniques is relatively new (Ashworth and Voogd, 1994). This development helps to fill a gap in the practical managerial implications of place marketing activity.

Historically, cities have competed for resources, residents and custom with this being indicative of place marketing activities occurring implicitly within their distinct markets. Indeed, critiques of place marketing have deemed it to be merely the formalisation of activities that occur naturally with Anholt (2006) arguing that cities are brands even where systematic promotion is absent. Place marketing definitions, such as Warnaby et al. (2002), centre on three aspects. First, governance is the responsibility of a range of 'place actors' that function and interact as stakeholders, rather than being the preserve of one organisation or else left to occur naturally. Secondly, there is a need to be responsive and attuned to the market's requirements. Finally, the process of transmitting the message to the intended audience entails a commodifying process whereby place marketers package the most desired or useful elements of their place product in such a way as to allow for favourable promotion. Conceptually the process of commodification rationalises the bundling of the place's social and economic benefits as a way to develop competitive advantage (Philo and Kearns, 1993). Significantly, this demonstrates the importance of viewing the city's product, first, as being integral rather than disparate and, secondly, in terms of how the intangible 'benefits' accrue to place users. Holism, in how the place is packaged, and imagery, in how this is conveyed, are both significant. However, the transference of marketing principles, chiefly that of maximising sales, can be difficult for place marketers with Ashworth and Voogd (1994) 
suggesting that the value of the package, or bundle of benefits, is often too complex to allow for this. As such, measuring impact may not capture reality or reflect the multiplicity of activities and interests involved.

Across these definitional aspects, one consistent feature that most place marketing efforts focus upon is that of promotion. 'Place promotion' has enjoyed a high degree of continuity through the history of place marketing's guises (Ward and Gold, 1994). Regardless of a place marketing strategy's target audience, message and communication forms, its primary role is to promote the location that it is representing. Considering that marketing principles are premised on the basis of exchange, in which case a demonstrable market need is satisfied, the focus on promotion, with its connotations of foisting a product which lacks credibility or is unwanted onto the market, has been questioned. Ave (1993), Borchert (1994) and Schmidt (1993) discuss problems with applying promotional techniques. Although imagery is crucial for promotional purposes (Smyth, 1994), the reality needs to be credible. In contrast, Warnaby and Medway (2004) ascribed segmentation and targeting as marketing techniques associated with the current stage of place marketing that were more developed and, potentially, insightful. If applied, this could help to reduce the prevalence of sales-driven approaches. For the 'place formation' process, this emphasises the importance of being marketing focused in identifying the elements of attractiveness that differentiate agglomerations.

To maximise the likelihood of this, places need to differentiate themselves effectively (Kavaratzis and Ashworth, 2005). Countering this, Holcomb (1994) saw inherent difficulties when places were commodified in that there was an inexorable tendency for standardised approaches. To combat this stressing a place's distinctiveness is a response to this predominance of identikit images (Kotler and Gertner, 2002). Any disparity between the projected image and the consumer experience could place finite limits on how readily these 
concepts can be applied. This suggests the importance of measuring, rather than assuming prescriptively, consumers' perceptions in order to ensure that the place product, which producers need to market, is evidence-based. Reinforcing this, Capik (2006) considered that the content of a place's image should be the outcome of analysing that respective place's product.

Systematic implementation of place marketing is therefore required. Empirical evidence, however, points to its implementation being unstructured and reactive (Ulaga et al., 2002). Understanding one's place users can allow the place marketing process to be influenced more proactively rather than the promotional efforts being misplaced or off-beam. Since place marketing should be driven by market principles and not solely on societal goals (van den Berg et al., 1990), this more attuned and responsive strategy is apt. Place marketing should reflect the demands of the targeted audience (Ashworth and Voogd, 1994), although the coalescence between the content of promotional messages as opposed to reality has been contested. If so, this suggests that place marketing needs to be grounded in an understanding of the relevant consumer base(s).

Urban place marketing categorisations have been sub-divided as follows: the individual place product, the cluster of urban products and, finally, the urban agglomeration in its entirety (van den Berg and Braun, 1999). Such a categorisation is reflective of the place marketing process being understood more systematically. The latter level of urban retail agglomeration is chiefly associated with identity and image building. However, where there is disparity between imagery as opposed to tangible reality, it could be questioned as to whether this provides sufficient substance and appeal for place users.

Ultimately, greater competitiveness should ensue from a more complete appreciation of this 'place formation' process. Appreciating the importance of competition, in terms of combating a rival or buttressing one's own position, is critical (Kotler et al., 1993) with this 
having occurred within a context of intensified levels of competitive activity (Warnaby et al., 2005). Hall (1993) attributed these concerns, which centre on the harshness of territorial competition, as the prime driver of place marketing. Achieving a marketing rather than sales oriented focus, as a way to understand one's place users, contributes to this goal of competitiveness. In this regard, Bramezza (1996) highlighted that it was imperative that urban management be market-oriented.

\section{Relevance of Retailing and Retail Consumers for Place Marketing}

Traditionally, retailing has not been accorded due attention or significance by governmental policy makers. Instead of the sector being valued, it has been denigrated as an activity dependent on more productive parts of the economy which generate greater worth. Consequently, it is viewed as parasitical (Kaldor, 1966) or, in a slightly more favourable light, as of mere ancillary benefit rather than being integral to the local economy. However, this negative perspective has been critiqued by Williams (1996) who views the sector as having a more positive role. Persky et al. (1993) highlighted the importance of reducing leakage, and thereby increasing retention, of trade locally. For place marketers, therefore, retailing can be a stimulant, instead of a dependent cost, to economic growth. Although the term 'secondary' is indicative of these negative or somewhat dismissive assumptions regarding retailing, Shaw and Williams (1992) commented that, despite being categorised as a secondary element, it was one of the main attractions for an urban centre. This view of the indispensability of retailing was reiterated by Evans (1997) and Page (1995), whilst Williams (1992) saw it as vital for economic development.

Understanding who one's place users are, whilst appreciating that they differ, is crucial (Hospers, 2006). Madsen (1992) noted that the range of functions and services offered by urban areas requires marketing activities to be directed to users. Notwithstanding this, the role of place users has not been given due acknowledgement within place management 
(Gower, 2008). The successful application of place marketing, though, is dependent on whether the existing, and potential, users consider there to be any basis in the imagery and content of the promotional messages. Significantly, the basis of a transmitted message should reflect the reality of what users experience or desire. In support of this, market research should reveal who a town centre's users are (Whitehand, 1983) with Page and Hardyman (1996) noting that the rationale for major expenditure in such locations needs to be justified through prior research. In short, place marketers need to work with an evidence base highlighting the nature of their existing, and prospective, place users.

A review of the literature on place users reveals a number of research gaps. Whereas Ulaga et al. (2002) examined place marketing strategies in the context of business to business customer decision-making, this paper considers consumers in a business to consumer context. Although this paper focuses on place users in a retail context and not on how they participate in the place branding process (Therkelsen and Halkier, 2004), there are parallels in its emphasise upon embedding a market focus. Rather than researching the impact of place marketing on place users, as advocated by Aiesha (2006), this study examines the underlying basis of what constitutes attractiveness in the earlier stage of 'place formation' through quantitative measurement of their perceptions. In doing so, it substantiates and builds upon the arguments advocated by Gower (2008) together with Insch and Florek (2008). The former noted that place management should be 'people-managed', in the sense that a sustainable approach recognises the need to incorporate the perspectives of place users, whilst the latter reviewed the nature of how 'place satisfaction' is understood. In contrast, this paper measures place users empirically with reference to urban retail agglomerations. They provide an ideal platform to access place users with their perceptions of the agglomeration revealing what exactly is driving their motivations to attend a particular agglomeration. 


\section{Proposed Antecedents of (Retail Related) Place Attractiveness}

Urban places and their retail components can be marketed and managed systematically by place marketers (Bennison et al., 2005; Teller and Elms, 2009). Within this, it is necessary to identify the manageable characteristics that contribute to the overall evaluated attractiveness and preference of that retail agglomeration. Three groups of characteristics, which are relevant across agglomeration formats, were identified (Teller, 2008; Teller and Reutterer, 2008) (see Figure 1). First, there are 'site related factors' such as accessibility and parking conditions. Secondly, are 'tenant related factors' such as the retail and non-retail tenant mix. Finally, there are 'environment related factors' represented by: atmosphere, ease of orientation and infrastructure. The construct of attractiveness was operationalised through three dimensions: satisfaction, retention proneness and patronage intention (Teller and Reutterer, 2008). These aspects are of particular relevance to place marketers as the constructs aim to capture the attractiveness and satisfaction people perceive in a place which affects the length of time they will stay and potential to return in the future.

Based on Finn and Louviere (1996), a positive (significant) effect between the perceived characteristics of an agglomeration, i.e. exogenous factors, and the three dimensions of evaluated attractiveness of an agglomeration, i.e. endogenous factors is proposed. As a result, the model comprises of 23 hypotheses (see Figure 1) with the exogenous factors, operationalised by two or more indicators each, being seen on the left and the three endogenous factors on the right hand side. The arrows indicate the relation and the effect, whereas the arrow heads show the direction of the effect. All constructs in this model were operationalised by using the scales of Teller et al. (2008). 
Figure 1: Hypotheses

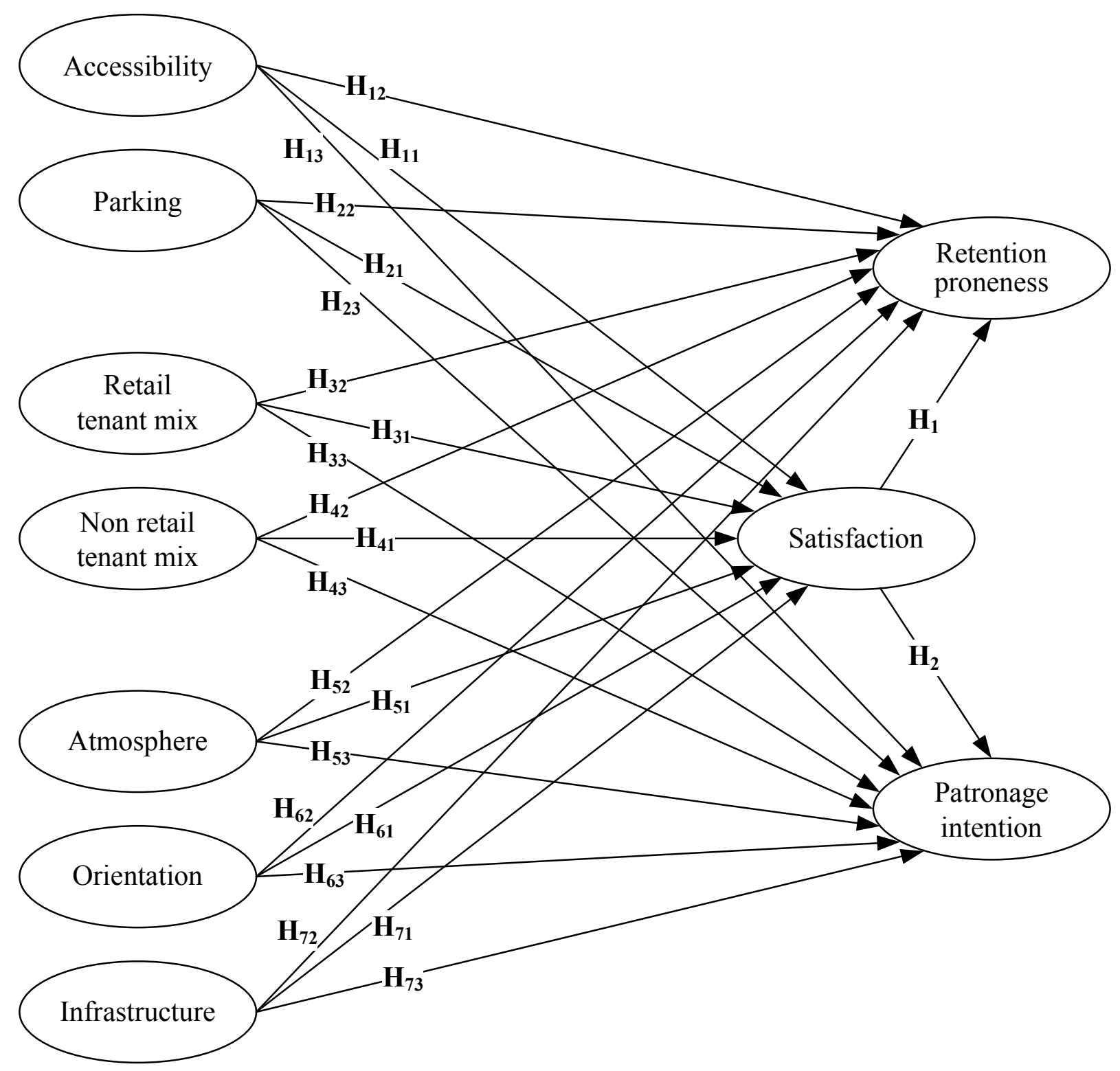

\section{Methodology}

The data were gathered at an urban retail agglomeration in a southern Austria capital city with a population of circa 25,000 . Researchers were located at the entry points of the town centre in order to access shoppers at the beginning of their shopping trip where interviewer administered questionnaires were conducted. A random sample of 486 was obtained representing retail related place users over a period of three weeks. The sample obtained reflects the structure of the city population at a household level however 
demographically the sample is not representative of the city. The data were analysed and the hypotheses tested using a structural equation modelling approach - e.g., Hair et al. (2009). The measurement validity of the exogenous and endogenous measurement models was tested according to Churchill (1979) and Bagozzi et al. (1991).

\section{Results}

Examining the model fit produces satisfactory results with local, global and parsimonious fit achieved according to the recommended values (Hu and Bentler 1991, 1999; Anderson and Gerbing 1988; see Table 1). From this, the empirical data prove to fit the proposed model to a satisfactory degree. Overall, ten effects were significant and consequently the respective numbers of hypotheses $\left(H_{n}\right)$ can be confirmed (see Table 1). In interpreting these results, the path coefficients which indicate the impact of effects between the three endogenous factors are significant. This suggests that any exogenous factors directly affecting satisfaction also have an indirect affect on retention proneness and patronage intention, and are, therefore, a determinant for all three endogenous factors. The retail tenant mix and atmosphere are the most important influencing factors. More specifically, the effects of retail tenant mix are strongest whereas there is a direct influence on the three endogenous factors. Atmosphere has a direct effect on satisfaction and retention proneness with patronage intention only being indirectly affected. Thereafter, the observable effects are mostly of middling or low significance. Orientation plays an important role with regard to patronage intention. Infrastructure has a significant impact on satisfaction. Accessibility and parking does not impact any of the endogenous factors and can therefore be seen of no direct importance to change the three dimensions of attractiveness. Finally, the squared multiple correlations $\left(r^{2}\right)$ of the endogenous factor satisfaction shows that a considerable share of variance is explained by the endogenous factors $\left(r^{2}=.503\right)$. These values are lower for the 
other two other factors patronage intentions $\left(r^{2}=.308\right)$ and in particular Retention proneness $\left(r^{2}=.264\right)$, thus meaning that other factors not included in the (conceptual) model (see Figure 1) provide further explanatory power.

Table 1: Antecedents of (retail related) town centre attractiveness

\begin{tabular}{|c|c|c|}
\hline $\begin{array}{l}\text { Hypo- } \\
\text { theses }\end{array}$ & Proposed effects & \\
\hline $\mathrm{H}_{11}$ & Accessibility $\rightarrow$ Satisfaction & - \\
\hline $\mathrm{H}_{21}$ & Accessibility $\rightarrow$ Retention proneness & - \\
\hline $\mathrm{H}_{31}$ & Accessibility $\rightarrow$ Patronage intention & - \\
\hline $\mathrm{H}_{12}$ & Parking $\rightarrow$ Satisfaction & - \\
\hline $\mathrm{H}_{22}$ & Parking $\rightarrow$ Retention proneness & - \\
\hline $\mathrm{H}_{32}$ & Parking $\rightarrow$ Patronage intention & - \\
\hline $\mathrm{H}_{13}$ & Retail tenant mix $\rightarrow$ Satisfaction & $.503 * * *$ \\
\hline $\mathrm{H}_{23}$ & Retail tenant mix $\rightarrow$ Retention proneness & $.150 *$ \\
\hline $\mathrm{H}_{33}$ & Retail tenant mix $\rightarrow$ Patronage intention & $.187 *$ \\
\hline $\mathrm{H}_{14}$ & Non-retail tenant mix $\rightarrow$ Satisfaction & - \\
\hline $\mathrm{H}_{24}$ & Non-retail tenant mix $\rightarrow$ Retention proneness & - \\
\hline $\mathrm{H}_{34}$ & Non-retail tenant mix $\rightarrow$ Patronage intention & - \\
\hline $\mathrm{H}_{15}$ & Atmosphere $\rightarrow$ Satisfaction & $.237 * * *$ \\
\hline $\mathrm{H}_{25}$ & Atmosphere $\rightarrow$ Retention proneness & $.377 * * *$ \\
\hline $\mathrm{H}_{35}$ & Atmosphere $\rightarrow$ Patronage intention & - \\
\hline $\mathrm{H}_{16}$ & Orientation $\rightarrow$ Satisfaction & - \\
\hline $\mathrm{H}_{26}$ & Orientation $\rightarrow$ Retention proneness & - \\
\hline $\mathrm{H}_{36}$ & Orientation $\rightarrow$ Patronage intention & $.230^{*}$ \\
\hline $\mathrm{H}_{17}$ & Infrastructure $\rightarrow$ Satisfaction & $.207 * *$ \\
\hline $\mathrm{H}_{27}$ & Infrastructure $\rightarrow$ Retention proneness & - \\
\hline $\mathrm{H}_{37}$ & Infrastructure $\rightarrow$ Patronage intention & - \\
\hline $\mathrm{H}_{1}$ & Satisfaction $\rightarrow$ Retention proneness & $.130 *$ \\
\hline $\mathrm{H}_{2}$ & Satisfaction $\rightarrow$ Patronage intention & $.236 * *$ \\
\hline
\end{tabular}

Caption:

-...t-values are not significant and consequently $\gamma$ is not shown; *..t-values are significant $(p<.05)$; **..tvalues are significant $(p<.01) ; * * * \ldots t$-values are significant $(\mathrm{p}<.001)$

Notions:

Global fit measures (recommended cut-off values in brackets): Absolute fit measure: RMSEA $(<.08)=.059$; Incremental fit measures: TLI/CFI (>.9/>.9)=.906/.923; Parsimony fit measures: Normed $\chi^{2}$ (CMIN/df) $(<3)=2.679$; Degrees of freedom $=333$;

\section{Conclusions}

This study demonstrates that the marketing of urban place product must be grounded in empirical evidence - in other words, shoppers' perceptions of a place. Thus, rather than marketing the urban product without reference to the needs of place users competitive advantage can be achieved through a specific and distinct targeted (retail related) product 
proposition. In particular this study has underscored the impact of the multi-faceted construct of attractiveness on the place users' satisfaction of the urban place product in two ways: the likelihood of extending their length of stay, and; their intensions to return to the town centre in the future (Teller and Reutterer, 2008). Consequently the identification and understanding of these factors can enable place marketers to craft and emphasise the urban product characteristics that are perceived to be most important, and, consequently the most valued, by place users. This, in turn, suggests rather than adopting a sales-driven perspective place marketers should instead take a consumer-driven approach to their marketing strategies through an appreciation, and systematic application, of the 'place formation' process.

Given that Anholt (2006) have noted that cities act as brands, even if this is implicit rather than through formalised marketing, the identification and then subsequent promotion of these significant characteristics lends credibility to 'place formation'. Subsequent promotion of an agglomeration should be based on how place users perceive and value it in its existing form, and not on how place marketers are seen to manipulate or mould their target consumers. In short, the output of the 'place formation' process should be to optimise a responsive, credible and useful urban product for place users. Concomitant with this identification of the most significant characteristics, there needs to be recognition that 'place formation' needs to be built upon strategy and substance. Anholt (2008) indicated that place marketing activities need to give this due recognition. In doing so, place marketing needs to stress these tangible characteristics rather than indistinct and arguably more contestable and less credible, images. By acting upon an understanding of one's place users, a more transparent place product can be promoted with this being a reflection of the need for place marketing to show maturation by being more concerted rather than unplanned.

Given the importance of retail agglomerations within the fabric of the urban landscape, the findings of this study suggest that packaging a bundle of characteristics that 
shoppers perceive to be the most significant in terms of attractiveness needs to be identified, understood and harnessed by place marketers. In this research, the retail tenant mix was most significant in this respect. However, the underlying elements that constituted this measure had a differing effect on shoppers overall perceptions of attractiveness, and thus a driver for consumer patronage of the town centre. Consistent with the view of Warnaby et al. (2006) that retailers are an important place marketing actor, the relative weighting shoppers attribute to these factors should be considered by managers in the formulation of their marketing strategies. Additionally, as in research focussing on supra-regional as well as other types of agglomeration formats (e.g. Teller, 2008; Teller and Reutterer, 2008), atmosphere was also a significant determinant of attractivess. Interestingly, in contrast to research that has focussed on different agglomerations, particularly created ones (e.g. Reimers and Clulow, 2004), variables such as accessibility and parking were of little, if any, significance.

As a part of this commodification process, place marketers should emphasis the characteristics that yield the greatest significance for the users of a place. The implications of such are two-fold. First, through careful consideration of the weighted dimensions that constitute the urban place product, place marketers can offer a differentiated product offering to their place users which, in turn, can be leveraged as a competitive advantage. Adopting this consumer-centric approach can lead to a greater dialogue with their consumers that can be used to incrementally tailor and adapt their market offerings and thus enable longer-term commercial success. Second, although the data analysis presented in this study underscored that the measures of accessibility and parking lacked significance, this does not, however, necessarily mean they are unimportant. Rather accessibility and parking should be considered as essential pre-condition variables, which, rather than actively differentiating between agglomerations, can be understood as taken for granted factors that consumers expect regardless of the agglomeration in question. Thus place marketers need to be aware that such 
variables are essential in building value and the satisfaction gained from using a place, but are not those that facilitate a competitive edge. Consequently, through disaggregating the multiple characteristics of a retail agglomeration, in this instance a town centre, and isolating those characteristics that influence the attractiveness of a particular urban place, alongside an appreciation of those that are considered to be axiomatic by place users regardless of the specific agglomeration, the 'place formation' process can be considered as a useful framework for place marketers when attempting to allocate their resources and provides a clear direction for their marketing endeavours.

Finally it has to be mentioned that the empirical setting of this study is inevitably reflective of central European regional and urban retail agglomerations. Moreover the shoppers under investigation display certain demographic and behavioural characteristics which may not be generalisable elsewhere. Further research should therefore attempt to replicate this study in other settings and focus on other place user groups.

\section{References}

Aiesha, R. (2006) Place marketing and the planning process. Proceedings of the CIRM Conference - Destinations and Locations: Exploring the Multiple Identities of Place pp. 1-2. Manchester: Manchester Metropolitan University,

Anderson, J.C. and Gerbing, D.W. (1988) Structural equation modelling in practice: A review and recommended two-step approach. Psychological Bulletin 103(3): 411-423.

Anholt, S. (2006) Is place branding a capitalist tool?, Place Branding 2(1): 1-4.

Anholt, S. (2008) Place branding: Is it marketing, or isn't it?, Place Branding and Public Diplomacy 4: 1-6.

Ashworth, G.J. and Voogd, H. (1994) Marketing and place promotion. In: J.R. Gold and S.V. Ward (eds.) Place Promotion: the use of publicity and marketing to sell towns and regions. Chichester: John Wiley, pp. 39-52.

Ave, G. (1993) Urban Planning and strategic urban marketing in Europe. In: G. Ave and F. Corsico (eds.) Urban Marketing in Europe. Turin: Turin Incontra, pp. 126-159.

Bagozzi, R.P., Yi, Y. and Phillips, L.W. (1991) Assessing construct validity in organizational research. Administrative Science Quarterly 36(3): 421-458.

Bennison, D.J., Warnaby G. and Davies B.J. (2005) Retailing and the marketing of urban places: a UK perspective. The International Review of Retail Distribution and Consumer Research 15 (2): 191-215. 
Borchert, J.G. (1994) Urban marketing: a review. In: G.O. Braun, J. Karn, H. Linemann, A. Schultz, G. Woosnam and J. Woosnam (eds.) Managing and Marketing to Sell Towns and Regions. Berlin: Deitrich Reimer Verlag, pp. 415-427.

Bramezza, I. (1996) The Competitiveness of the European City and the Role of Urban Management in Improving the City's Performance Amsterdam: Thesis Publishers.

Capik, P. (2006) Regional marketing strategies and network models in competing regions FDI attraction mechanisms in Central Eastern Europe. Proceedings of the CIRM Conference - Destinations and Locations: Exploring the Multiple Identities of Place; 2030. Manchester: Manchester Metropolitan University.

Churchill, G. A. (1979) A paradigm for developing better measures of marketing constructs. Journal of Marketing Research 16(1): 64-73.

Evans, R. (1997) Regenerating Town Centres. Manchester: Manchester University Press.

Finn, A. and Louviere, J. J. (1996) Shopping center image, consideration, and choice: anchor store contribution. Journal of Business Research 35(3): 241-251.

Gower, R. (2008) People-managed places. Journal of Place Management and Development 1(3): 315-321.

Guy, C. (2007) Planning for retail development: a critical view of British experience. London: Routledge.

Hair, J. F., Black, W. C., Babin, B. J., and Anderson, R. E. (2009) Multivariate Data Analysis, Upper Saddle River, New Jersey: Prentice Hall.

Hall, P. (1993) Forces shaping Urban Europe, Urban Studies, 30(6): 893-898.

Holcomb, B. (1994) City make-overs: marketing the post-industrial city. In: J.R. Gold and S.V. Ward (eds.) Place Promotion: the use of publicity and marketing to sell towns and regions. Chichester: John Wiley, pp. 115-133

Hospers, G.J. (2006) Borders, Bridges and Branding: The transformation of the Oresund region into an imagined space. European Planning Studies 14(8): 1015-1033.

Howard, E. (1997) The management of shopping centres: conflict or collaboration? International Review of Retail Distribution and Consumer Research 7(3): 263-285.

$\mathrm{Hu}, \mathrm{L}$. and Bentler, P. M. (1991) Fit indices in covariance structure modelling: sensitivity to underparameterized model misspecification. Psychological Methods 3(4): 425-453.

$\mathrm{Hu}$, L. and Bentler, P. M. (1999) Cutoff criteria for fit indexes in covariance structure analysis: Conventional criteria versus new alternatives. Structural Equation Modelling 6(1): 1-55.

Insch, A. and Florek, M. (2008) A great place to live, work and play: Conceptualising place satisfaction in the case of a city's residents. Journal of Place Management and Development 1(2): 138-149.

Jewell, N. (2001) The fall and rise of the British mall, Journal of Architecture, 6 (4): 317-378.

Kaldor, N. (1966) Causes of the Slow Rate of Growth in the United Kingdom. Cambridge: Cambridge University Press.

Kavaratzis, M. and Ashworth, G.J. (2005) City Branding: an effective assertion of identity or a transitory marketing trick?, Tijdschrift voor Economische en Sociale Geografie, 96 (5): 506-514.

Kotler, P. and Gertner, D. (2002) Country as brand, products and beyond: a place marketing and brand management perspective Journal of Brand Management 9(4/5): 249-262.

Kotler, P., Asplund, C., Rein, I. and Haider, D. (1999) Marketing Places Europe: Attracting Investments, Industries, and Visitors to European Cities, Communities, Regions and Nations. Harlow: Financial Times Prentice Hall.

Kotler, P., Haider, D. and Rein, I. (1993) Marketing Places: Attracting Investment, Industry, and Tourism to Cities, States and Nations. New York: The Free Press. 
Madsen, H. (1992) Place-marketing in Liverpool: a review. International Journal of Urban and Regional Research 16(4): 633-640.

Nelson, R. L. (1958) The selection of retail locations. New York: F.W. Dodge Corporation.

Page, S.P. (1995) Urban Tourism. London: Routledge.

Page, S.P. and Hardyman, R. (1996) Place marketing and town centre management: a new tool for urban revitalization. Cities 23 (3): 153-164.

Persky, J. Ranney, D. and Wiewel, W. (1993) Import substitution and local economic development, Economic Development Quarterly 7(1): 18-29.

Philo, C. and Kearns, G. (1993) Culture, history, capital: a critical introduction to the selling of places. In: G. Kearns and C. Philo (eds.) Selling Places. Oxford: Pergamon Press, pp. $1-32$.

Reimers, V. and Clulow, V. (2004) Retail concentration: a comparison of spatial convenience in shopping strips and shopping centres. Journal of Retailing and Consumer Services 11(4): 207-221.

Reutterer, T. and Teller, C. (2009) Store format choice and shopping trip types. International Journal of Retail and Distribution Management 37(8): 695-710

Schmidt, K. (1993) City marketing in Germany. In: G. Ave and F. Corsico (eds.) Urban Marketing in Europe. Turin: Turin Incontra, pp. 183-195.

Schnedlitz, P., and Teller, C. (2008) Das Einkaufszentrum als Agglomerationsklasse begriffliche Diskussion und empirische Evaluierung von Agglomerationseffekten [Shopping centers as a distinct agglomeration format - conceptual discussion and empirical evaluation of agglomeration effects]. In M. Gruber (eds.) Agglomerationseffekte und Bestandverhaeltnisse in Einkaufszentren [Agglomeration effects and leasing agreements in shopping centers] Vienna: Manz, pp. 1-52.

Shaw, G. and Williams, A. (1992) Tourism, development and the environment: the eternal triangle. In: C.P. Cooper and A. Lockwood (eds.) Progress in Tourism, Recreation and Hospitality Management. Chichester: John Wiley, pp. 47-59.

Short, J.R. and Kim, Y-H. (1998) Urban crises/urban representations: selling the city in difficult times. In: T. Hall and P. Hubbard (eds.) The Entrepreneurial City: Geographies of Politics, Regimes and Representations, Chichester: John Wiley.

Smyth, H. (1994) Marketing the City: the role of flagship developments in urban regeneration. London: E\&F Spon.

Teller, C. (2008) Shopping streets versus shopping malls - determinants of agglomeration format attractiveness from the consumers' point of view. International Review of Retail, Distribution and Consumer Research 18(4): 381-403.

Teller, C. and Elms, J. R. (2009) Managing the Attractiveness of Evolved and Created Retail Agglomeration Formats. Marketing Intelligence and Planning 28 (1): 25-45.

Teller, C. and Reutterer, T. (2008) The evolving concept of retail attractiveness: What makes retail agglomerations attractive when customers shop at them? Journal of Retailing and Consumer Services 15(3): 127-143.

Teller, C., Reutterer, T. and Schnedlitz, P. (2008) Hedonic and utilitarian shopper types and created retail agglomerations. International Review of Retail, Distribution and Consumer Research 18(3): 283-309.

Therkelsen, A. and Halkier, H. (2004) Umbrella place branding: a study of friendly exoticism and exotic friendliness in coordinated national tourism and investment promotion, Discussion Paper 26. Aalborg: Centre for International Studies, Aalborg University.

Ulaga, W., Sharma, A. and Krishnan, R. (2002) Plant location and place marketing: understanding the process from the business customer's perspective. Industrial Marketing Management 31(5): 393-401. 
Van den Berg, L. and Braun, E. (1999) Urban competitiveness, marketing and the need for organising capacity. Urban Studies 36(5/6): 987-999.

Van den Berg, L., Klaassen, L.H. and van der Meer, J. (1990) Marketing Metropolitan Regions. Rotterdam: European Institute for Comparative Urban Research.

Ward, S.V. and Gold, J.R. (1994) Introduction. In: J.R. Gold and S.V. Ward (eds.) Place Promotion: the use of publicity and marketing to sell towns and regions. Chichester: John Wiley, pp. 1-19.

Warnaby, G. and Bennison, D. (2006) Reciprocal urban place marketing and co-branding? Retail Applications. Place Branding 2: 297-310.

Warnaby, G. and Medway, D. (2004) The role of place marketing as a competitive response by town centres to out-of-town retail developments. International Review of Retail Distribution and Consumer Research 14(4): 457-477.

Warnaby, G., Bennison, D. and Davies, B.J. (2005) Retailing and the marketing of urban places: a UK perspective. International Review of Retail, Distribution and Consumer Research 15(2): 191-215.

Warnaby, G., Bennison, D. and Medway, D. (2006) The role of SME retailers in locational differentiation. Proceedings of the CIRM Conference - Destinations and Locations: Exploring the Multiple Identities of Place; 167-173, Manchester: Manchester Metropolitan University.

Warnaby, G., Bennison, D., Davies, B.J. and Hughes, H. (2002) Marketing UK Towns and Cities as Shopping Destinations. Journal of Marketing Management 18(9-10): 877-904.

Whitehand, J. (1983) Land-use structure, built form and agents of change. In: R. Davies and A. Champion (eds.) The Future for the City Centre. London: Academic Press.

Williams, C.C. (1992) The contribution of regional shopping centres to local economic development: threat or opportunity? Area 24(3): 289-294.

Williams, C.C. (1996) Rethinking the role of retailing and consumer services in local economic development: a British perspective. Journal of Retailing and Consumer Services 3(1): 53-56.

Williams, C.C. (1996) Rethinking the role of retailing and consumer services in local economic development: a British perspective. Journal of Retailing and Consumer Services 3(1): 53-56. 